\title{
THE RELATIONSHIP OF SCHOOL MATERIALS AND RESOURCES TO READING LITERACY: AN INTERNATIONAL PERSPECTIVE
}

\author{
Victor Froese \\ Professor, Department of Language Education \\ 2125 Main Mall \\ University of British Columbia \\ Vancouver, BC V6T 1Z4, Canada \\ E-mail: froesev@unixg.ubc.ca
}

\begin{abstract}
There is great interest in the effect of school resources on academic achievement, but it is seldom that an opportunity arises in which this relationship may be examined in an international milieu. This paper presents the types of resources available in the 27 countries participating in the International Association for the Evaluation of Educational Achievements (IEA) Reading Literacy Study, and explores the relationship of the most pertinent variables to achievement. More particularly, the focus is on school and classroom libraries, their description and use, and on classroom teacher's practices as they relate to library use.

In my fourth year of public school teaching I was appointed as Head Teacher of a threeroom rural school with about 100 students. In this position I was responsible for all aspects of running the school including spending a small budget on materials, supplies, and books. A locked hallway cupboard approximately 30 inches by 30 inches by 12 inches deep contained what was termed "the library" and it had traditionally been accessible to students at a few designated times for "checking out" books, so I was told. Needless to say, I found the situation appalling, and two years later when graduate school beckoned, I was pleased to leave the school with three classroom libraries each approximately three times the size of the original. How many books were in those spaces do you suppose?

Many years later having earned two graduate degrees in Reading Education I became Head of the Department of Language Education at the University of British Columbia, and what should I find located there but a School Librarianship program under my supervision! And when I became the Research Coordinator for the BC component of the IEA Reading Literacy Study in the early '90s, and in this capacity gained access to information from 32 different countries, numbers of "books" again took on a new significance. While "literacy" was the focus of attention in the study, I casually mentioned this wealth of data regarding resources to Anne Clyde who indicated a keen interest in it, and encouraged me to tease out those aspects of interest to librarians. And that brings us to the topic of this paper and to my presentation at the IASL-ATLC Conference in Vancouver.

You will have noticed that the word "books" was used inside quotation marks since it oversimplifies what libraries are all about, but it is the stereotyped symbol of libraries in common use. As I was writing this article the University of British Columbia opened a new library building and celebrated its faculty authors; the Vancouver Sun headline read "It's a big week for books at UBC." Therefore it is with "books" and "magazines" that I wish to begin my story; then we will move to the uses of school and classroom libraries; then to teachers' practices; and finally we will examine some vignettes relating various variables with achievement. This approach is supported by the type of data gathered as part of the IEA Reading Literacy Study of 1991and first reported in How in the world do students read? (Elley, 1992).
\end{abstract}




\section{THE IEA READING LITERACY STUDY}

Before proceeding it is necessary to sketch in some of the details of the study in order to contextualize the data. In 1990-91 about 210,000 students and over 10,000 teachers from 32 countries (more correctly jurisdictions) participated in the study of reading literacy sponsored by the International Association for the Evaluation of Educational Achievement, an organization based in The Hague, that conducts international research in many aspects of education. The general purpose was to show how well nine-year-olds (referred to as Population A) and 14-year-olds (referred to as Population B) read, and to identify which student, teacher, and school attributes were related to the development of literacy. While 32 jurisdictions participated not all did so at both levels and hence when dealing with Population A we have only 27 countries. For a variety of reasons, the age criteria resulted in approximately half the countries testing in Grades 3 and 8, and the other half in Grades 4 and 9, and one country (New Zealand) tested students in Grades 5 and 10. Various attempts have been made to address this dilemma since it has a potential impact on the interpretation of the results. The term "reading literacy" was coined for this study and means "the ability to understand and use those written language forms required by society and/or valued by the individual." The focus was on material commonly found in the home, school, the community, and the workplace in the participating countries. Students responded to three types of texts, or domains, which were referred to as narrative, expository, and document. For the 9-year-olds a test of word recognition was included in order to check whether weaknesses in comprehension were related to the inability to decode highly familiar words. Additionally three questionnaires were administered. One was given to students and asked about personal information and interests, details about home, about reading habits, about homework, and about the reading instruction they were receiving. A second was given to teachers and it inquired about their educational background, about the class being tested, about teaching activities, about aims of reading instruction, about the classroom and school libraries, and about school organization. The third questionnaire asked principals about their training, about community resources, the school library and resources, about instructional time, and about the principal's role. All instruments had input from representatives of the participating jurisdictions, a steering committee oversaw the process, and pilot studies in most countries preceded the formation of the final instruments. The international data is aggregated at the school level and most countries sampled approximately 150 schools (range 70-298; mean 156); samples were weighted to assure the desired level of accuracy.

Clearly this study has produced a wealth of information which cannot be reported within the parameters of this presentation, and therefore the emphasis will be on the nine-year-olds (Population A) which are typically in grade three or four in most countries. Details of a number of aspects of the IEA study have been reported elsewhere (Froese, 1995a; Froese, 1995b).

\section{SCHOOL AND CLASSROOM LIBRARIES}

Before tackling the issue of library size it seemed important to establish whether schools had libraries since a range of countries from economically poor to well-off participated in the study. Further, students came from small rural areas as well as large urban ones. The relevant geographic information is presented graphically in Table 1 and 2. 
table 1

$\Delta$ 
Table 2 
A careful study of the data in Table 2 indicates that, for example, in six countries approximately half of the schools are "village or rural" in location (Indonesia, Italy, Netherlands, Portugal, Sweden, Switzerland, Trinidad \& Tobago), whereas only two jurisdictions (Hong Kong, Singapore) are primarily urban "city of $1 \mathrm{M}$ or more". The majority of countries have half or more of their schools in "village or rural" or "small town" settings. This information may assist in understanding the data with respect to book holdings.

According to teachers' estimates (see Table 1) about half the countries have school libraries in virtually every school (e.g. over 90\%); on the other hand in six countries less than half the schools have school libraries (the exception is Cyprus which reports all books at the classroom level). However, the presence of a school library is only part of the picture since the size of the collection is the better indicator of resources, and that is discussed under the next heading. Only in seven countries are classroom libraries found in virtually all schools (e.g., over 90\%) although in most countries over half the schools have classroom libraries with the exception of Venezuela in which only 29\% of schools have them.

It is also instructive to look at the library visitation frequency (Table 3) and the percentage students borrowing books from school and classroom libraries (Table 4). In approximately half the countries most students $(90 \%+)$ borrow books from the school library (in Cyprus this applies to the classroom level library since it does not report school libraries). And the use of classroom level libraries is considerably less, although their real use may be hidden by this statistic: that is, they are used for classroom reading and these books are not necessarily taken out. According to the reports of teachers (see Table 3), only about one-third of 9-year-old students visit school libraries at least once per week, and a very small percentage visit the library more frequently. Even more discouraging is the percentage of students "hardly ever" visiting the school library-25\% averaged over all countries, but over $30 \%$ in 11 countries!

\section{SIZE OF SCHOOL AND CLASSROOM LIBRARIES}

Estimating the number of books or magazines in a school or classroom library is not an easy matter as it turns out. Such information was requested of teachers and of principals; teachers were asked to select a range into which their school library fell (e.g. increments of 20 to a maximum of "100 or more"), principals to estimate the number of volumes. This information is presented in Tables 5, 6 and 7 .

In an attempt to further understand the relationship of library size and socioeconomic variables, the top 10 and the bottom 10 countries on the Composite Development Index (CDI) were analyzed. This index, similar to the Human Development Index was developed for the IEA study and consists of six components-Gross National Product per capita, public expenditure per student, life expectancy, percent low birth weight, newspapers per 1000 population, and percent of adult literacy-indicators of economy, health, and literacy. Table 8 presents the 10 highest ranked countries on the CDI--Switzerland, Sweden, Norway, Iceland, Finland, United States, Canada (BC), Netherlands, West Germany (this study was initiated before Germany's reunification), and Denmark, and the 10 lowest ranking countries in the study--Indonesia, Venezuela, Portugal, Hungary, Trinidad \& Tobago, Greece, Cyprus, Singapore, Spain, and Hong Kong, along with the expenditures per student in terms of US dollars and the percentage of schools having school and classroom libraries.

In general there is a positive relationship in the percentage of schools having school and classroom libraries and expenditures per student, especially when the highest and the lowest countries on the CDI Index are compared. The average expenditure for the highest ranking countries is US\$ 3,964 whereas the average for the lowest ten countries is US\$ 773; the average number of books per school library is 3,426 for the top schools and 1,637 for the others. However there are a few exceptions to the generalization since in Spain, Singapore, and Hungary relatively high levels of libraries are present in spite of lower expenditures per student. 
table 3

$\Delta$ 
Table 4

$\Delta$ 
Table 5 
Table 6

$\Delta$ 
Table 7 
Table 8

$\Delta$ 
Teachers' estimates of books, magazines, and newspapers in the school library (see Table 5 \& 6) are somewhat different from the estimates made by the school principal in Table 8 . The percentage of libraries in the "100 or more" range is depressingly small-only nine countries report over $25 \%$ of schools in this category-however, it must be remembered that the majority of schools are in rural locations. According to these reports the majority of countries have school libraries in the under 60 book categories! The situation for magazines and newspapers is equally discouraging since most countries carry 5 or less per school library.

\section{CLASSROOM PRACTICES BY TEACHERS}

In this section we turn our attention to the classroom practices of teachers which are related to the uses of libraries. Since it is assumed that teachers of 9-year-olds know something about children's books, it is interesting to see if they read children's books and if they read to children in their classes-both good modelling behaviours. Table 9 documents the frequency of reading children's books, and it appears that in about one-half of the countries 30 percent or more teachers read children's books on a "weekly or more" basis, and in most countries they read them on a "monthly" basis. Table 10 shows that in nine countries over half the teachers read to children "daily," and in another 10 countries over half the teachers read to children "one or two times per week." Unfortunately in each country a small number of Grade 3 and 4 teachers "almost never" read to children.

It also seems important to know whether teachers instruct students in library skills and whether they encourage them to use the library. Table 11 indicates that in about one-half the countries one-third of the teachers provide library skill training " 1 or 2 times per week" whereas in the majority of the countries about one-quarter of the teachers teach library skills on a "monthly" basis. A sizable proportion of teachers in most countries "almost never" teach library skills. In Table 12 we see the frequency with which teachers in each country encourage student to use the library. In over half the countries about one-third of the teachers encourage students to use the library "almost daily" and in most countries about one-third of the teachers encourage them "one or two times per week." The contrast between the information in the two tables seems to suggest that more "preaching" then "practicing" is occurring.

Table 13 indicates that teaching children to choose their own books is not rated highly as an aim of instruction. Only a small percentage of teachers in each country "agree" that this is an important aim, and a small proportion "disagree" that it is an important aim of instruction. Table 14 shows that assessing students' reading interests is something that over one-half of teachers in most countries do on a monthly basis, and another one-fourth of teachers in one-third the countries do on a "once per week or more " basis. The majority of teachers can be said to assess students' reading interests once per term or more frequently.

\section{RELATIONSHIP BETWEEN ACHIEVEMENT AND SELECTED VARIABLE}

In order to consider the relationship of reading literacy achievement to selected library variables it is necessary to have more specific data than was available to the writer with respect to all participating countries. Therefore we turn now to data relating to Canada (BC) which represents a jurisdiction exactly at the international mean of 500. Approximately 2,682 students in Grade 3 formed the sample for British Columbia with 157 classrooms participating (the weighted number used in calculation, however, was 142) and their reading literacy achievement was 502 for Narrative, 499 for Expository, and 500 for Documents (average 500 over three domains). A follow-up study indicated that had the test been given to Grade 4 students the mean score would have been 552, and if give to Grade 5 students 586. At the Grade 3 level about $10 \%$ of the teachers are male and about $90 \%$ female; English is the mother tongue of about $90 \%$ of the teachers and other languages represent about $10 \%$. The average teacher has about four years of university training, and about 13 years of teaching experience. 
Table 9 
Table 10 
Table 11

$\Delta$ 
Table 12 
Table 13 
I selected a number of variables to expand, most which were dealt with generally in the previous sections of this paper, and to show their relationship to achievement. These are: teaching in the three domains, assessing students' reading interests, the number of books, magazines \& newspapers in the school and classroom library, frequency of borrowing books, visiting the library, and the amount of time spent teaching narrative, expository and document type text.

We look first at the effect of teachers teaching narrative, expository, and document type text and how each is related to the others. In short, does teaching narrative improve reading narrative, and so on. The answer is not particularly clear since teaching narrative and expository text infrequently (i.e., three or four times per year) seems related to achievement as is more frequent teaching (i.e., weekly or daily). Further, almost never teaching documents appears to result in the highest achievement!

As indicated in the international data, the majority of teachers appear to assess students' reading interests on a term or monthly basis, and the graph indicates that in BC there are classrooms in which teachers assess students more frequently and in general continue to get slightly better achievement.

The number of books, magazines, and newspapers in the school library as estimated by teachers does not indicate a predictable relationship with reading achievement in the three domains. The reason for this is not clear, but teachers' estimates of these variables are somewhat at odds with the principals' estimates, and somewhat at odds with what one would reasonably expect. Students' estimates of books in their homes, on the other hand, are very good predictor of achievement as may be seen in Table 15.

While borrowing books from school libraries shows a strong relationship with reading achievement in all the domains; curiously, borrowing books from classroom libraries does not. Further, the frequency of visiting the school library is also relate to achievement although not quite as directly, especially when expository text is considered.

In this last section we have explored the relationship of selected variables to the actual reading literacy achievement in one of the jurisdictions-Canada (BC) - for which such information was available. While some variables presented puzzling pictures, two in particular showed very clear relationships. Students who have the opportunity to borrow books from libraries have a considerable achievement advantage over those who cannot, and the number of books in students' homes as predicted by them shows that those who have few books (i.e., none to 10)lag considerably behind in achievement when compared to those who have many (i.e., 100 or more).

\section{CONCLUDING COMMENTS}

The data from the IEA Reading Literacy Study completed in the early '90s provides some interesting insights into school library resources and their use. Further, we get a perspective of teachers' aims, objectives, and teaching practices as they relate to literacy and libraries.

When looking at literacy and library resources, clearly there are great needs in many countries and very limited resources, yet in some countries very reasonable literacy achievement results are obtained even without large expenditures. The data does suggest that countries with higher per student expenditures do have more school and classroom libraries, that students in classrooms that have access to school libraries achieve higher than those who don't, and that students who have many books in their homes achieve at higher levels than those who don't.

The relationships of resource and practices to achievement were explored to determine what could be learned. Evidence from this study indicates that the relationships are not simple or as direct as one might hope. All of this has reminded me of a story by Garrison Keillor. Faced with a summer in separation, the narrator and his girlfriend agree to read ten books in common, five picked by him and five by her "so that, although apart, we would have the same things on our minds at the same time and would think of each other." (Keillor, 1985, 15) Not surprisingly the agreement failed. The titles selected by Keillor's characters to impress each other remained unread and engendered feelings of guilt rather than the intended unity. The 
Table 14 
Table 15 
problem for us remains to design research questions that minimize confusion of purpose and allow us to collectively think some of the same things at the same time.

\section{REFERENCES}

Elley, W.B. (1992). How in the world do students read? Hamburg: International Association for the Evaluation of Educational Achievement.

Froese, V. (1995a). A comparison of teacher strategies, aims and activities in two countries participating in the IEA reading-literacy study. In Pamela Owen \& Peter Pumfrey (Eds.) Curriculum and assessment issues: Messages for teachers, Volume 2 (pp. 162-185). London: Falmer Press.

Froese, V. (1995b). The global literacy classroom. In Marilyn Chapman \& James Anderson (Eds.) Thinking globally about language education (pp. 117-130). Vancouver: Research and Development in Global Studies, Centre for the Study of Curriculum and Instruction, University of British Columbia.

Keillor, G. (1985). Lake wobegon days. New York: Viking. 